\section{REFERENCES}

1. Fauci AS, Clifford LH. Human immunodeficiency virus (HIV) disease. AIDS and related disorders. In: Isselbacher, et al, eds. Harrison's Principles of Internal Medicine. 13th ed. New York, NY: McGraw-Hill, Inc; 1994.

2. Bartlett JC. HIV infection and surgeons. Curr Probl Surg 1992;29:197-280.

3. Whitfield G, Stotter A, Graham RM, Wiselka MJ. Operative procedures in patients subsequently found to be human immunodeficiency virus positive. Br J Surg 1995;82:991-993.

4. Consten ECJ, van Lanschot JJB, Henny CP, Slors JF, Danner SA, Brummelkamp WH. General operative aspects of human immunodeficiency virus infection and acquired immunodeficiency syndrome. J Am Coll Surg 1995;180:366-380.

5. Quebbeman EJ, Telford GL, Wadsworth K, Hubbard S, Goodman H, Gottlieb MS. Double gloving-protecting surgeons from blood contamination in the operating room. Arch Surg 1992;127:213-217.

6. Raahave D, Bremmelgaard A. New operative technique to reduce surgeons' risk of HIV infection. J Hosp Infect 1991;18:177-183.

7. Moss AR, Bacchetti P, Osmond D, et al. Seropositivity for HIV and development of AIDS or AIDS-related conditions: three year follow-up of the San Francisco General Hospital cohort. $\mathrm{Br}$ Med J 1988;296(6624):745-750.

8. Whitney TM, Macho JR, Russell TR. Appendicitis in acquired immunodeficiency syndrome. Am J Surg 1992;164:467-471.

9. Deziel DJ, Hyster MJ, Doolas A, et al. Major abdominal operations in acquired immunodeficiency syndrome. Am Surg 1990;56:445-450.

10. Pugliese G. HIV postexposure prophylaxis recommendations. Infect Control Hosp Epidemiol 1996;17:475.

11. Centers for Disease Control and Prevention. Update: provisional reocmmendations for chemoprophylaxis after occupational exposure to HIV. MMWR 1996;45:468-472.
12. Baltimore D. Lessons from people with non progressive HIV infection. N Engl J Med 1995;332:259-260.

113. Stein M, O'Sullivan P, Wachtel T, et al. Causes of death in persons with human immunodeficiency virus infection. Am J Med 1992;93:387-390.

14. Wexner SD, Smithy WB, Milsom JW, Dailey TH. The surgical management of anorectal diseases in AIDS and pre-AIDS patients. Dis Colon Rectum 1986;29:719-723.

15. Grunfeld C. What causes wasting in AIDS? N Engl J Med 1995;333:123-124.

16. Bizer LS, Pettorino R, Ashikari A. Emergency abdominal operations in the patient with acquired immunodeficiency syndrome. J Am Coll Surg 1995;180:205-209.

17. Diettrich NA, Cacioppo JC, Kaplan G, Cohen SM. A growing spectrum of surgical disease in patients with human immunodeficiency virus/acquired immunodeficiency syndrome. Arch Surg 1991;126:860-866.

18. Lowy AM, Barie PS. Laparotomy in patients infected with human immunodeficiency virus: indications and outcome. $\mathrm{BrJ}$ Surg 1994;81:942-945.

19. Whitney TM, Brunel W, Russell TR, Bossart KJ, Schecter WP. Emergent abdominal surgery in AIDS: experience in San Francisco. Am J Surg 1994;168:239-243.

20. Burack J, Mandell M, Bizer L. Emergency abdominal operations in the patient with acquired immunodeficiency syndrome. Arch Surg 1989;124:285-286.

21. Davidson T, Allen-Marsh TG, Miles AJG, et al. Emergency laparotomy in patients with AIDS. Br J Surg 1991;78:924-926.

22. Wilson SE, Robinson G, Williams RA, et al. Acquired immune deficiency syndrome (AIDS). Indications for abdominal surgery, pathology, and outcome. Ann Surg 1989;210:428-434.

23. LaRaja RD, Rothenberg RE, Odom JW, Mueller SC. The incidence of intra-abdominal surgery in acquired immunodeficiency syndrome: a statistical review of 904 patients. Surgery 1989;104:175-179.

\title{
Cost-Effectiveness of HIV Screening in Acute Care
}

\section{Gina Pugliese, RN, MS; Martin S. Favero, PhD Medical News Editors}

In January 1993, the CDC recommended that acute-care hospitals and associated clinics in which the prevalence of HIV infection was $1 \%$ or more offer routine voluntary HIV screening to inpatients and outpatients aged 15 to 54 years. Implementation of such a guideline would have resulted in testing approximately 3 million patients in 1990 . The costeffectiveness of this recommendation is not known.

Dr. Douglas Owens of Stanford University, Stanford, California, and colleagues at Washington University Medical School in St. Louis, Missouri, recently evaluated the cost-effectiveness of a voluntary screening pro- gram using a decision model. The results indicated that during the first year, an HIV screening program implemented in acute-care hospital settings in which the seroprevalence of HIV infection is $1 \%$ or more would result in the identification of approximately 110,000 undetected cases of HIV infection. The program would result in the expenditure of approximately $\$ 71$ million for testing and counseling, and expenditures of approximately $\$ 2$ billion for incremental medical care for the patients identified as having HIV infection during the first year of screening. When the seroprevalence of HIV is $1 \%$, the cost-effectiveness of screening is $\$ 47,200$ per year of life saved. When the effect of early identification of HIV infection on the patient's quality of life also is considered, screening is less cost-effective. Screening-induced reductions in risk behavior improve the cost-effectiveness of screening by preventing the transmission of HIV.

The authors concluded that the cost-effectiveness of screening for HIV in acute-care settings, when the seroprevalence is $1 \%$, is within the range of other accepted interventions, exclusive of the effect on the quality of life. However, the cost-effectiveness of screening is affected substantially by the effect of screening on the quality of life and by the degree to which persons identified as having HIV infection reduce risk behaviors that may transmit infection.

FROM: Owens DK, Nease RF, Harris RA. Cost-effectiveness of HIV screening in acute care settings. Arch Intern Med 1996;156:394-404 